\title{
Optimasi Jaringan Wireless PT. TASPEN dengan RADIUS Server dan Firewall Filter Rules
}

PT. TASPEN Wireless Network Optimization using RADIUS Server and Firewall Filter Rules

\author{
Rahmat Novrianda Dasmen ${ }^{1}$, Akhmad Khudri ${ }^{2}$ \\ ${ }^{1}$ Teknik Komputer, Universitas Bina Darma \\ ${ }^{2}$ Komputerisasi Akuntansi, Universitas Bina Darma \\ E-mail: ${ }^{1}$ rahmat.novrianda.d@ gmail.com, ${ }^{2}$ khudri@ binadarma.ac.id
}

\begin{abstract}
Abstrak
PT. TASPEN merupakan BUMN yang telah menerapkan jaringan wireless, tetapi memiliki beberapa kekurangan ataupun permasalahan sehingga mengganggu kualitas jaringan wireless PT. TASPEN. Adapun permasalahan yang terjadi adalah kecepatan internet menjadi sangat lambat karena user yang bukan karyawan pun sangat mudah terhubung ke jaringan wireless PT. TASPEN. Hal ini dikarenakan belum adanya pengamanan seperti user dan password khusus untuk penggunaan jaringan wireless PT. TASPEN. Selain itu, beberapa karyawan juga terkadang menggunakan jaringan wireless PT. TASPEN untuk membuka media sosial sehingga menimbulkan overload penggunaan bandwidth PT. TASPEN. Oleh karena itu, pada penelitian dengan menggunakan Metode Action Research ini, peneliti menerapkan RADIUS Server untuk mendata user khususnya karyawan PT. TASPEN serta memberikan hak akses (user dan password) yang berbeda-beda untuk setiap karyawan. Selain itu, peneliti juga memanfaatkan Firewall Filter Rules untuk memblok media sosial bagi user yang terhubung ke jaringan wireless agar kualitas kecepatan internet pada PT. TASPEN dapat terjaga.
\end{abstract}

Kata kunci: Jaringan Wireless, RADIUS Server, Firewall Filter Rules, Action Research

\begin{abstract}
PT. TASPEN is a state-owned company that has implemented a wireless network, but has several shortcomings or problems that disrupt the quality of the wireless network of PT. TASPEN. The problem that occurs is the internet speed becomes very slow because users who are not employees are very easy to connect to the wireless network of PT. TASPEN. This is because there is no security such as a special user and password for the use of PT. TASPEN wireless network. In addition, some employees also sometimes use PT. TASPEN wireless network to open social media, causing an overload of PT. TASPEN bandwidth usage. Therefore, in this research using the Action Research Method, the researcher implemented the RADIUS Server to record users, especially employees of PT. TASPEN and provide access rights (user and password) that are different for each employee. In addition, researchers also use Firewall Filter Rules to block social media for users connected to wireless networks so that the quality of internet speed at PT. TASPEN can be awake.
\end{abstract}

Keywords: Wireless Network, RADIUS Server, Firewall Filter Rules, Action Research 


\section{PENDAHULUAN}

Saat ini, Jaringan wireless sangatlah berguna bagi kehidupan sehari-hari, terutama sebagai penunjang operasional pada suatu bangunan contohnya Perusahaan. Jaringan wireless tersebut juga biasanya telah terhubung dengan layanan internet, sehingga sering kali terjadi beberapa permasalahan, salah satu contohnya adalah lambatnya ataupun menurunnya kecepatan jaringan internet tersebut. Ada beberapa hal yang menjadi faktor penyebab permasalahan tersebut, misalnya padatnya pengguna dalam suatu jaringan wireless dan juga besarnya kapasitas bandwidth yang digunakan oleh pengguna (sebagai contoh : Pengaksesan media sosial yang membutuhkan bandwidth cukup besar). Oleh karena itu, pada penelitian ini peneliti akan mengambil salah satu contoh objek penelitian yang mengalami permasalahan tersebut. adapun objek penelitian saat ini adalah PT. Dana Tabungan dan Asuransi Pegawai Negeri Perusahaan Perseroan atau secara singkat disebut PT. TASPEN (Persero) yang merupakan salah satu BUMN di Kota Palembang yang beralamat pada JL. Jenderal Sudirman Km. 4 No. 104 Palembang. Untuk menunjang pelayanannya, PT. TASPEN telah mengembangkan jaringan komputer yang dimilikinya dengan memanfaatkan teknologi jaringan wireless, akan tetapi masih terdapat kekurangan dan permasalahan pada pengembangan jaringan wireless ini.

Terdapat permasalahan utama yang terjadi, yaitu kecepatan internet jaringan wireless pada PT. TASPEN saat ini sangat lambat. Hal ini disebabkan oleh dua faktor paling berpengaruh, yaitu permasalahan pertama tidak adanya pembatasan user yang terhubung ke dalam jaringan wireless bahkan kebanyakan user bukanlah karyawan PT. TASPEN sehingga bandwidth PT. TASPEN terbagi kebanyak user yang tidak terotorisasi dan menyebabkan bandwidth yang diterima masing-masing karyawan PT. TASPEN pun sangat kecil (kecepatan internet sangat lambat). Selain itu, permasalah kedua adalah masih banyak user yang memanfaatkan jaringan wireless PT. TASPEN untuk membuka media sosial, dimana hal ini juga memakan bandwidth yang besar dan juga berpengaruh terhadap kecepatan internet user lainnya menjadi lambat. Oleh karena pemasalahan tersebut, pada penelitian ini dilakukan optimasi jaringan wireless dengan mengembangkan RADIUS Server untuk memberikan hak akses berupa user dan password yang berbeda-beda untuk karyawan PT. TASPEN. Penelitian sebelumnya juga mengembangkan autentikasi yang berbeda-beda untuk setiap user tetapi memanfaatkan teknologi Captive Portal [1], kemudian pada beberapa penelitian lainnya juga mengembangkan teknologi RADIUS Server dengan objek yang berbeda, seperti pada STIPER Sriwigama Palembang [2]. Selain itu, pada beberapa penelitian sebelumnya telah dijelaskan bahwa RADIUS Server digunakan sebagai autentikasi hotspot [3], RADIUS Server juga digunakan untuk analisis pemanfaatan bandwidth pada off-time kantor [4] dan bahkan penelitian sebelumnya telah melakukan pengaturan alokasi bandwidth dengan mengoptimasi RADIUS Server [5]. Selain itu, pada penelitian ini juga akan diimplementasikan Firewall Filter Rules yang akan digunakan untuk memblok akses beberapa media sosial, seperti Youtube, Instagram dan Facebook. Pada penelitian sebelumnya, Firewall Filter Rules dapat digunakan untuk meningkatkan Keamanan Jaringan berbasis Mikrotik [6], kemudian pada penelitian lainnya Firewall Filtering juga digunakan untuk mengoptimalisasi keamanan jaringan wireless [7], serta penelitian yang paling berkaitan adalah penelitian yang menggunakan Firewall sebagai pembatas akses pelajar agar tidak bisa mengakses konten berbau isu sara dan pornografi [8]. Oleh karena itu, pada penelitian ini akan diterapkan kedua teknologi yaitu RADIUS Server dan Firewall Filter Rules untuk mengoptimasi jaringan wireless PT. Taspen baik dalam hal pembatasan pengguna (user) dan pembatasan penggunaan situs yang memakan bandwidth besar (seperti : media sosial Youtube, Instagram dan Facebook) sehingga memaksimalkan kualitas kecepatan jaringan internet untuk pengguna (user) di dalam jaringan wireless tersebut. 


\section{METODE PENELITIAN}

\subsection{Tahapan Penelitian}

Pada diagram di bawah ini, dijelaskan tahapan-tahapan ataupun alur bagaimana penelitian saat ini dilakukan untuk memberikan solusi dari permasalahan yang telah dibahas dalam pendahuluan di atas.

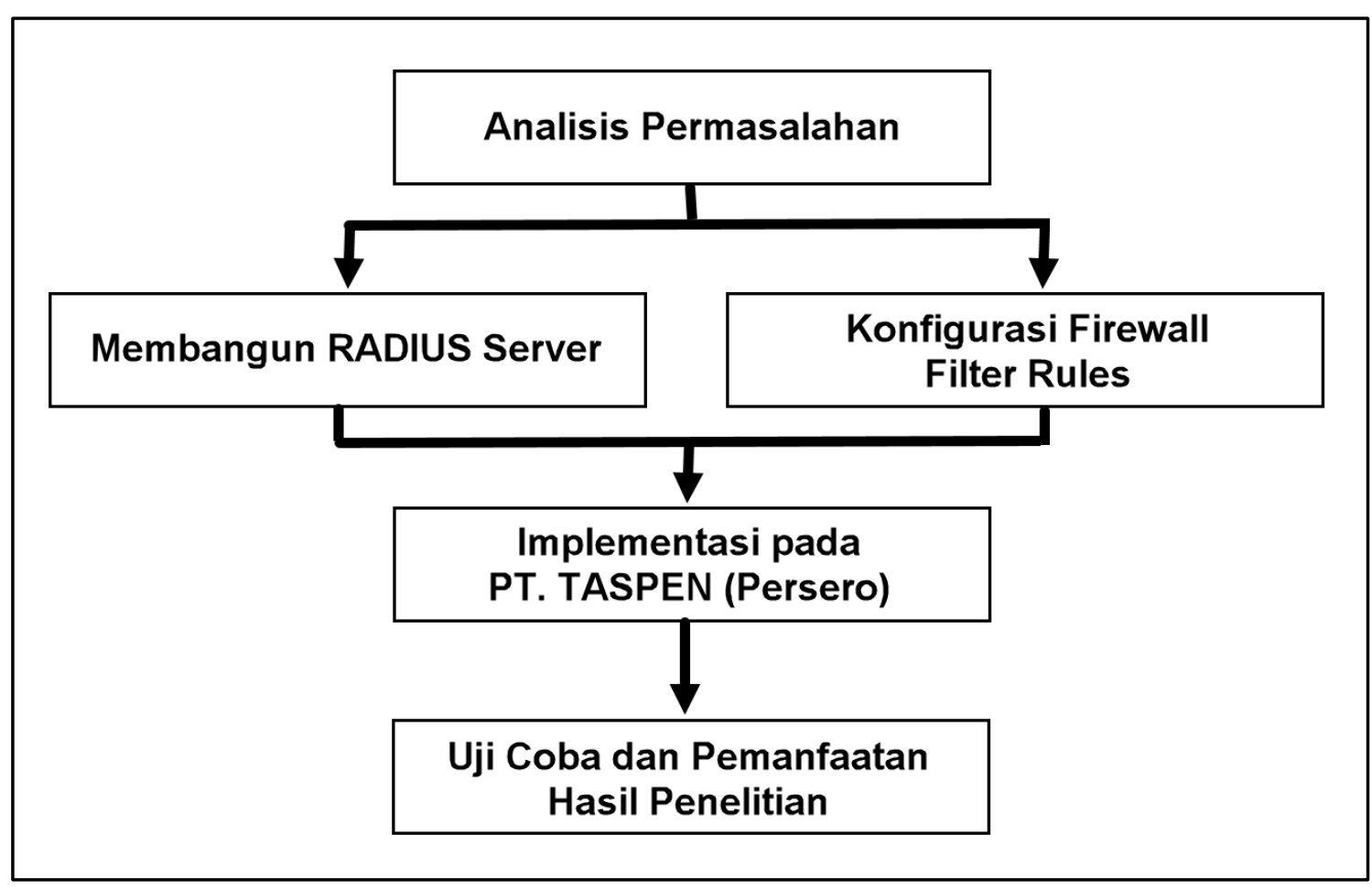

Gambar 1 Diagram Tahapan - Tahapan Penelitian

Dari diagram pada Gambar 1 di atas, dapat dijelaskan secara ringkas tentang tahapantahapan penelitian yang dilakukan saat ini. Adapun tahapan awalnya adalah Analisis Permasalahan, dimana pada penelitian ini permasalahan yang terjadi adalah lambatnya ataupun menurunnya kecepatan internet pada jaringan wireless sehingga dari analisis diperoleh 2 faktor utama penyebab permasalahan tersebut, yaitu banyaknya pengguna (user) yang terhubung ke dalam jaringan wireless tersebut tidak terbatas (tidak memiliki pembatas user) dan banyak user sering mengakses media sosial yang memakan banyak bandwidth (dalam hal ini media sosial yang paling sering digunakan adalah Youtube, Instagram dan Facebook). Oleh karena permasalahan tersebut, maka pada tahapan selanjutnya dilakukan 2 solusi yaitu dengan membangun RADIUS Server dan Konfigurasi Firewall Filter Rules. Dapat dijelaskan bahwa RADIUS Server akan memberikan user dan password hanya kepada pengguna (user) yang diizinkan sehingga dalam hal jumlah pengguna (user) telah dibatasi serta Konfigurasi Firewall Filter Rules dimanfaatkan untuk mem-blokir media sosial yang memakan bandwidth besar, seperti Youtube, Instagram dan Facebook. Kemudian, tahapan selanjutnya adalah menerapkan RADIUS Server dan Firewall Filter Rules pada objek penelitian yang mengalami permasalahan Jaringan Wireless seperti yang telah dipaparkan. Setelah itu, tahapan terakhir adalah melakukan evaluasi dengan melakukan uji coba dan juga pemanfaatan hasil penelitian pada PT. TASPEN (Persero).

\subsection{Metode Action Research}

Dalam proses pembangunan RADIUS Server dan Firewall Filter Rules pada penelitian ini digunakan Metode Action Research, dimana metode ini merupakan salah satu bentuk 
rancangan penelitian, serta dapat mendeskripsikan, menginterpretasi dan menjelaskan suatu kondisi sosial pada saat yang bersamaan dengan melakukan intervensi dengan tujuan untuk perbaikan ataupun partisipasi [9]. Gambar 1 berikut ini merupakan tahapan dari metode penelitian action research [10]:

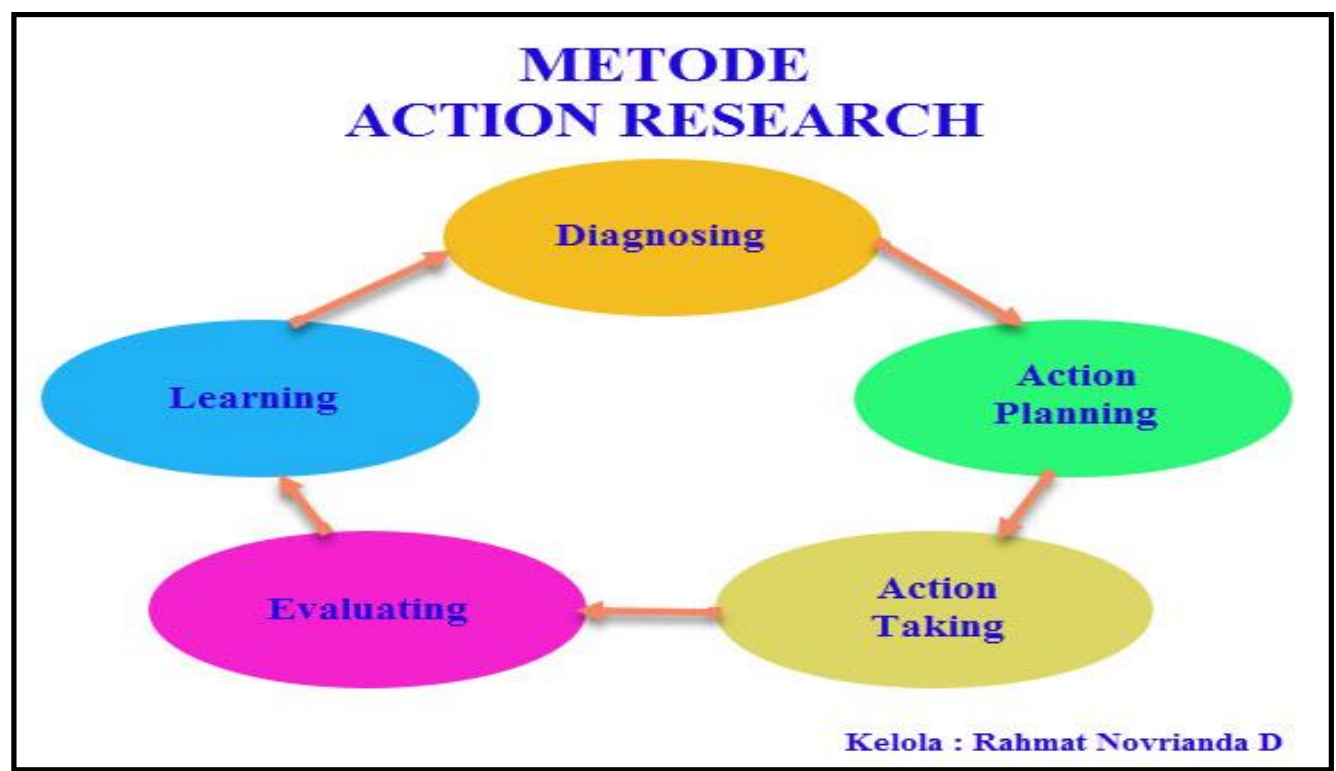

Gambar 2 Metode Action Research [11]

\subsection{Diagnosing}

Pada tahapan diagnosing, peneliti menganalisis permasalahan yang terjadi pada PT. TASPEN, terutama dalam hal Jaringan Wireless. Adapun permasalahan yang terjadi telah dibahas pada pembahasan sebelumnya, dimana kualitas kecepatan jaringan internet pada jaringan wireless PT. TASPEN menjadi sangat lambat. Kemudian, peneliti menganalisis juga penyebabnya, dimana terdapat dua penyebab utama yang mengakibatkan kecepatan internet menjadi lambat atau dengan kata lain bandwidth yang dibagi sangat kecil. Penyebab pertamanya adalah padatnya traffic user yang disebabkan karena siapapun dapat dengan mudah terhubung ke dalam jaringan wireless PT. TASPEN tanpa memerlukan autentikasi apapun, serta penyebab keduanya adalah terdapat user mengakses media sosial yang membutuhkan bandwidth besar dengan memanfaatkan jaringan wireless PT. TASPEN sehingga mempengaruhi bandwidth yang diterima user lainnya tentunya akan sangat kecil.

\subsection{Action Planning}

Berikut tahapan penelitian selanjutnya adalah action planning, dimana peneliti membuat perencanaan solusi untuk permasalah yang dialami jaringan wireless PT. TASPEN dengan memanfaatkan teknologi RADIUS Server dan Firewall Filter Rules. Teknologi RADIUS Server akan dipergunakan untuk memberikan autentikasi berupa user dan password yang berbeda-beda untuk setiap user pada PT. TASPEN dan Firewall Filter Rules akan diatur untuk menutup akses user pada jaringan wireless PT. TASPEN terhadap penggunaan media sosial, seperti: Youtube, Instagram dan Facebook. Selain itu, kedua teknologi ini juga secara tidak langsung meningkatkan keamanan jaringan wireless PT. TASPEN, dengan kata lain optimasi jaringan wireless PT. TASPEN akan lebih maksimal.

Sebelum menerapkan kedua teknologi tersebut, peneliti juga harus melakukan beberapa persiapan ataupun perencanaan, antara lain desain topologi yang ada pada PT. TASPEN saat ini, data perangkat jaringan pada PT. TASPEN dan data beberapa user yang diberikan otoritas untuk dapat menggunakan jaringan wireless PT. TASPEN. Berikut ini gambar dan tabel data-data tersebut secara berurutan ditampilkan: 


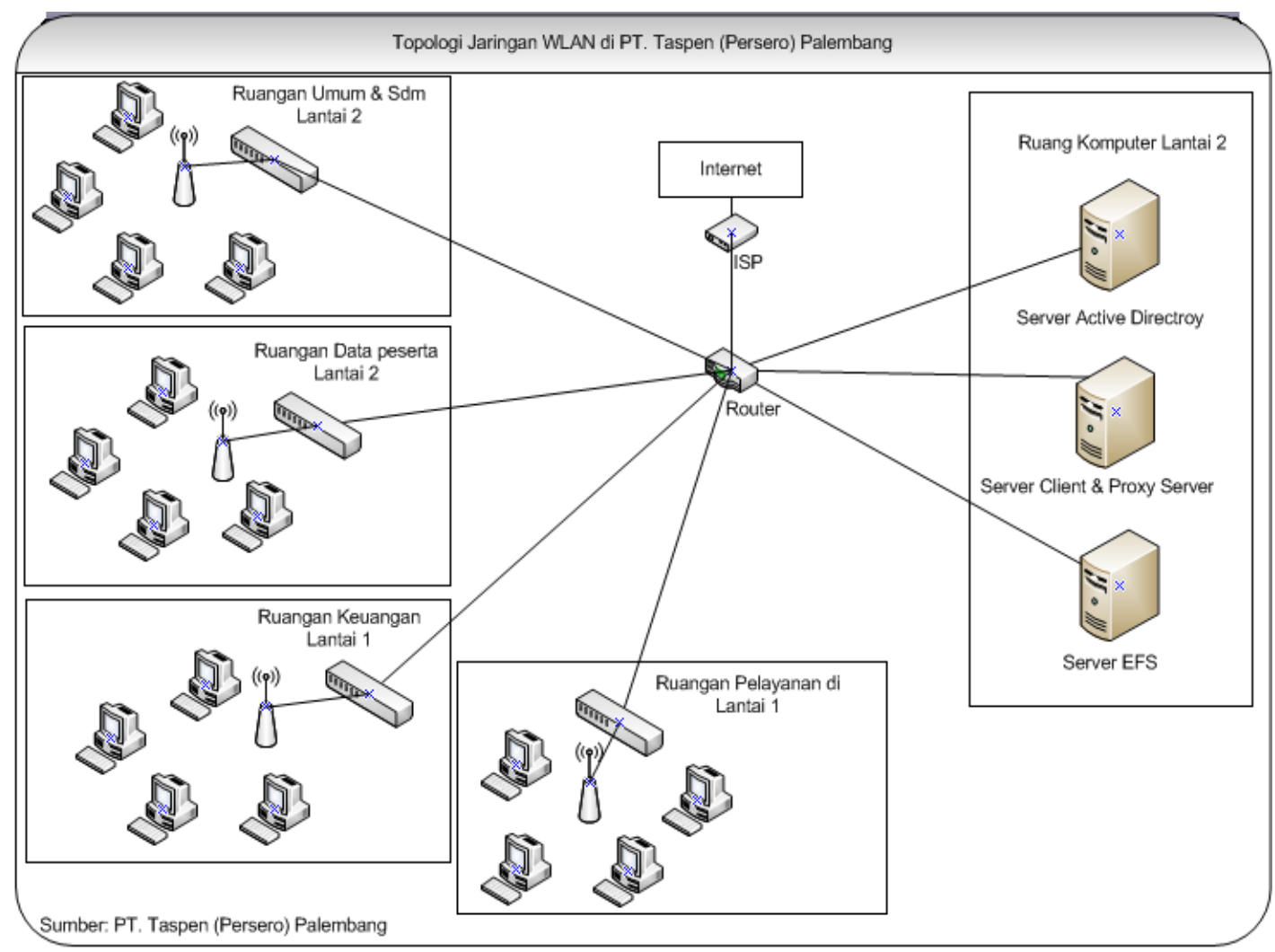

Gambar 3 Topologi PT. TASPEN

Tabel 1 Perangkat Jaringan PT. TASPEN

\begin{tabular}{|c|c|c|c|}
\hline NO & Ruangan & Perangkat & Jumlah \\
\hline 1 & Ruangan Server & $\begin{array}{c}\text { Server } \\
\text { Router }\end{array}$ & $\begin{array}{c}3 \text { Unit } \\
1 \text { Unit }\end{array}$ \\
\hline 2 & Ruangan Umum \& SDM & $\begin{array}{c}\text { Workstation } \\
\text { Switch } \\
\text { Access point }\end{array}$ & $\begin{array}{c}10 \text { Unit } \\
1 \text { Unit } \\
1 \text { Unit }\end{array}$ \\
\hline 3 & Ruangan Data Peserta & $\begin{array}{c}\text { Workstation } \\
\text { Switch } \\
\text { Access point }\end{array}$ & $\begin{array}{c}5 \text { Unit } \\
1 \text { Unit } \\
1 \text { Unit }\end{array}$ \\
\hline 4 & Ruangan Pelayanan & $\begin{array}{c}\text { Workstation } \\
\text { Switch }\end{array}$ & $\begin{array}{c}9 \text { Unit } \\
1 \text { Unit } \\
1 \text { Unit }\end{array}$ \\
\hline 5 & Ruangan Keuangan & Workstation \\
Switch & $\begin{array}{c}10 \text { Unit } \\
1 \text { Unit } \\
1 \text { Unit }\end{array}$ \\
\hline
\end{tabular}

Tabel 2 User yang diberikan otoritas

\begin{tabular}{|c|c|c|}
\hline Ruangan & Username & Password \\
\hline \multirow{4}{*}{ Lantai 1 Ruang Pelayanan } & krismanto & Kr1sm@nt0 \\
\cline { 2 - 3 } & agung & A6un9 \\
\cline { 2 - 3 } & herwannurdin & H3rw@ nnurd1n \\
\cline { 2 - 3 } & desri & D3sr1 \\
\hline \multirow{4}{*}{ Lantai 2 Ruang Keuangan } & toto karyono & Tot0k@ ry0no \\
\cline { 2 - 3 } & suyono & Suy@n0 \\
\cline { 2 - 3 } & agnes s & Agn35 \\
\hline
\end{tabular}




\section{HASIL DAN PEMBAHASAN}

\subsection{Action Taking}

Pada tahapan action taking, peneliti melakukan konfigurasi untuk membangun teknologi RADIUS Server dan Firewall Filter Rules. Seluruh konfigurasi dilakukan menggunakan Mikrotik routerboard dan konfigurasi ditulis pada Graphic User Interface (GUI) dari software Winbox. Adapun keseluruhan tahapan konfigurasi dituliskan pada software Winbox dan pada tahapan action taking ini ditampilkan hasil akhir konfigurasi RADIUS Server dan Firewall Filter Rules.

\subsubsection{Konfigurasi RADIUS Server}

RADIUS Server digunakan untuk membatasi akses user yang dapat terhubung pada jaringan wireless PT. TASPEN, dengan cara membuat link login serta memberikan user dan password yang berbeda-beda untuk user ataupun karyawan yang telah terdata dan diberikan otoritas login ke jaringan wireless PT. TASPEN. Berikut ini tampilan berturut-turut hasil konfigurasi RADIUS Server pada gambar 4, list user yang telah memperoleh otoritas login pada gambar 5, tampilan scanning wifi hotspot PT. Taspen pada gambar 6 dan tampilan halaman login untuk user yang telah memiliki user dan password pada gambar 7.

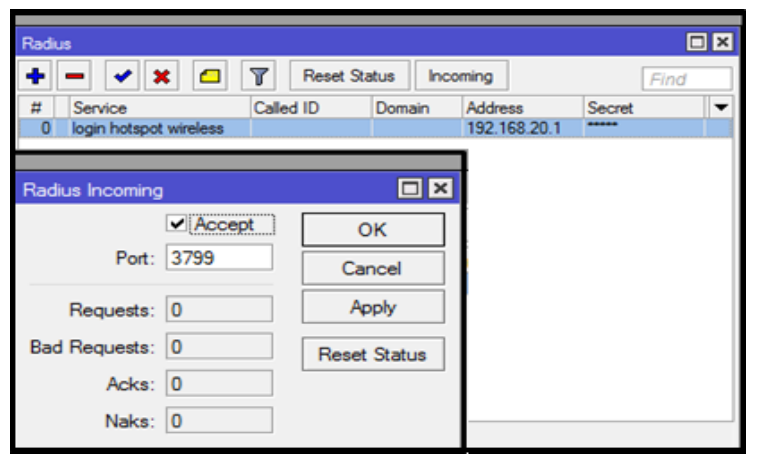

Gambar 4 Hasil Konfigurasi RADIUS Server

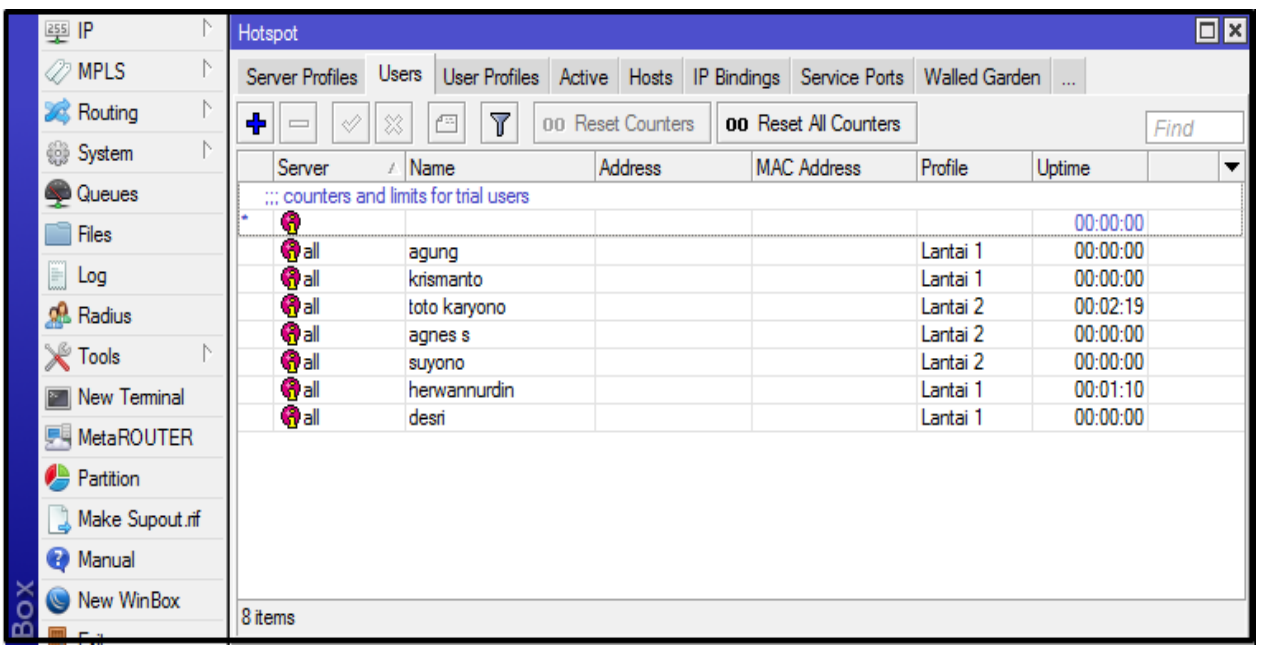

Gambar 5 List user yang telah memiliki otoritas login 


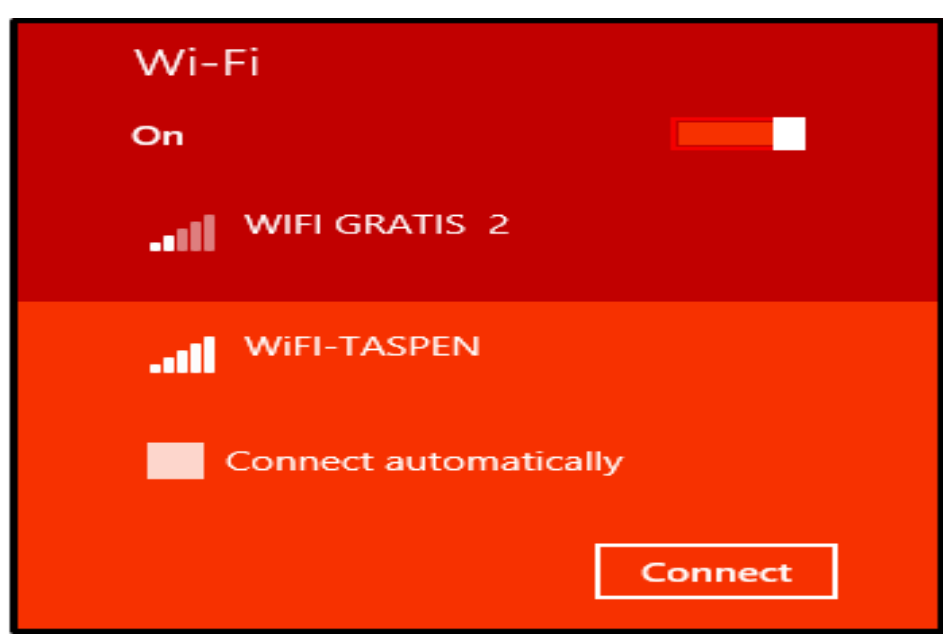

Gambar 6 Hasil scanning wifi hotspot PT. TASPEN

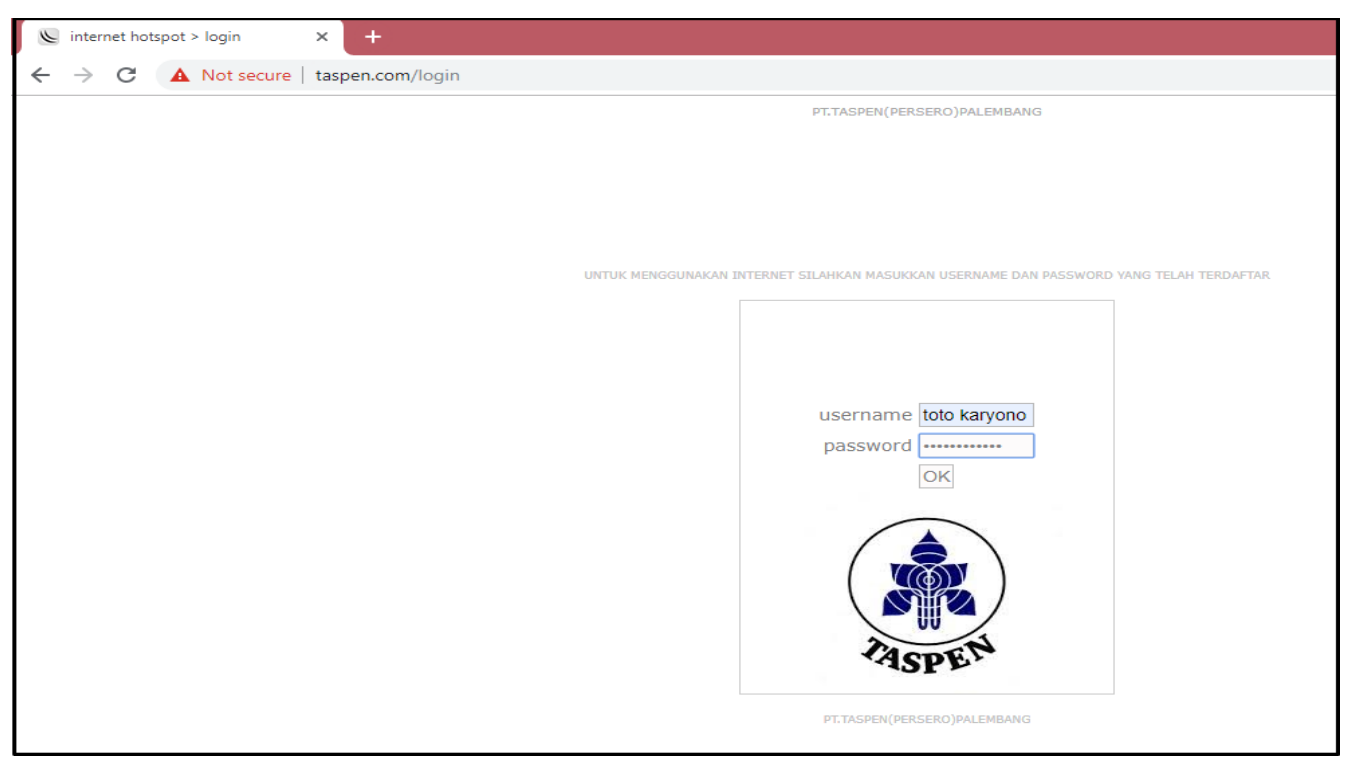

Gambar 7 Tampilan halaman login ke jaringan wireless PT. TASPEN

Dari hasil konfigurasi RADIUS Server di atas, terlihat pada gambar 7 untuk dapat terhubung ke Jaringan Wireless PT. TASPEN (Persero), setiap pengguna (user) wajib memiliki username dan juga password yang telah terdaftar pada RADIUS Server. Hal ini menjelaskan bahwa tanpa username dan password yang telah terdaftar pada RADIUS Server, pengguna (user) tidak dapat lagi memanfaatkan layanan internet pada PT. TASPEN Persero.

\subsubsection{Konfigurasi Firewall Filter Rules}

Firewall Filter Rules digunakan untuk membatasi akses penggunaan media sosial saat user terhubung ke dalam jaringan wireless PT. TASPEN, dimana pada penelitian ini dilakukan pemblokiran terhadap media sosial Youtube, Instagram dan Facebook. Dapat dijelaskan kembali bahwa user yang telah login dan terhubung ke dalam jaringan wireless PT. TASPEN ataupun hotspot PT. TASPEN tidak akan bisa lagi mengakses media sosial Youtube, Instagram dan Facebook. Berikut ini ditampilkan gambar hasil konfigurasi dari Firewall Filter Rules. 


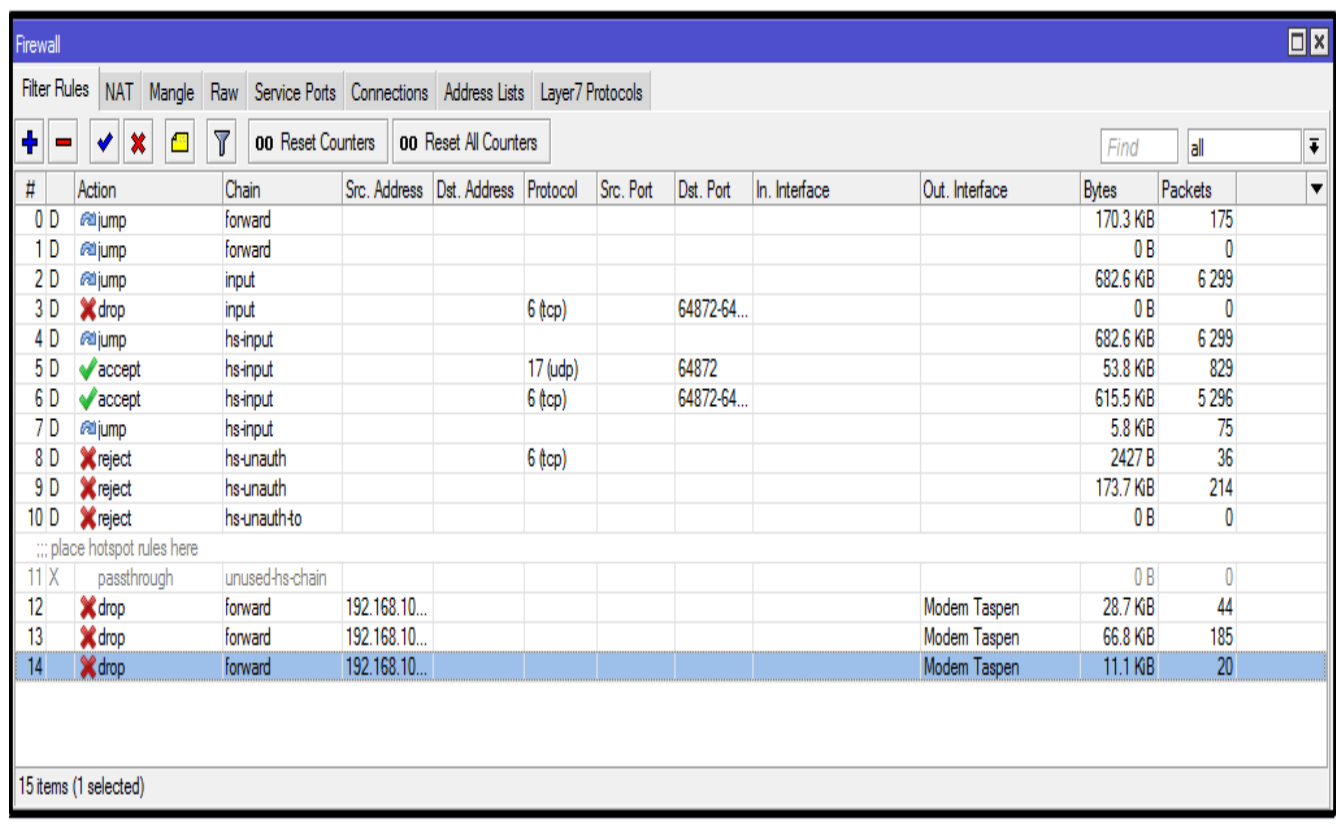

Gambar 8 Hasil konfigurasi Firewall Filter Rules

\subsection{Evaluating}

Tahapan evaluating merupakan tahapan yang berisikan beberapa pengujian dari hasil penelitian yang telah diperoleh, pada penelitian ini ditampilkan pengujian hasil dari konfigurasi RADIUS Server dan Firewall Filter Rules.

\subsubsection{Pengujian RADIUS Server}

Untuk pengujian RADIUS Server sendiri dilakukan dengan cara melakukan autentikasi ataupun melakukan login ke dalam jaringan wireless PT. TASPEN (Hotspot PT. TASPEN) dan hasil konfigurasi dinyatakan berhasil jika login yang dilakukan juga berhasil dengan baik. Berikut ini tampilan keberhasilan login dari dua user yang telah memperoleh otoritas.

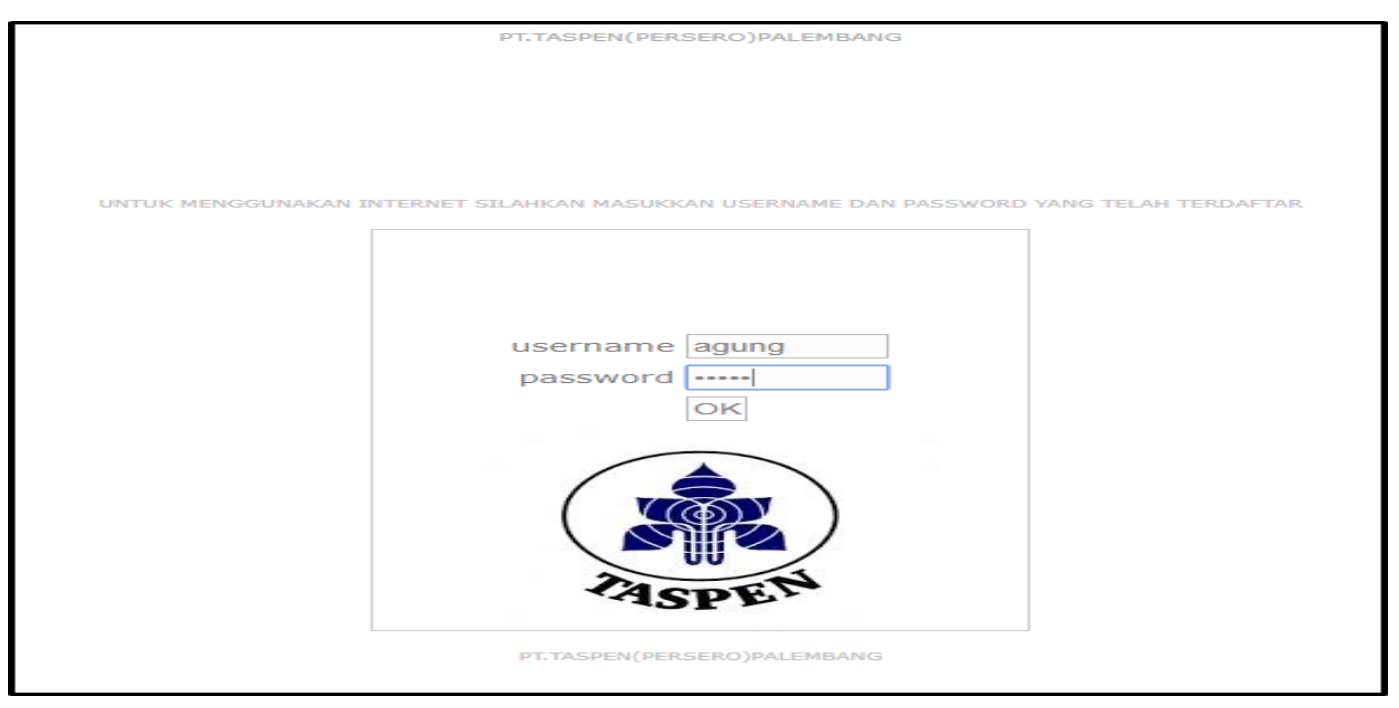

Gambar 9 Login user agung 


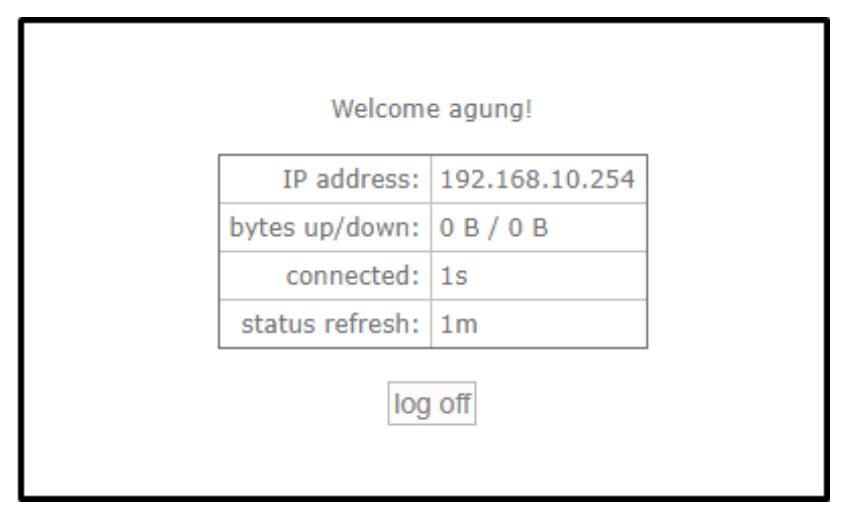

Gambar 10 User agung berhasil login

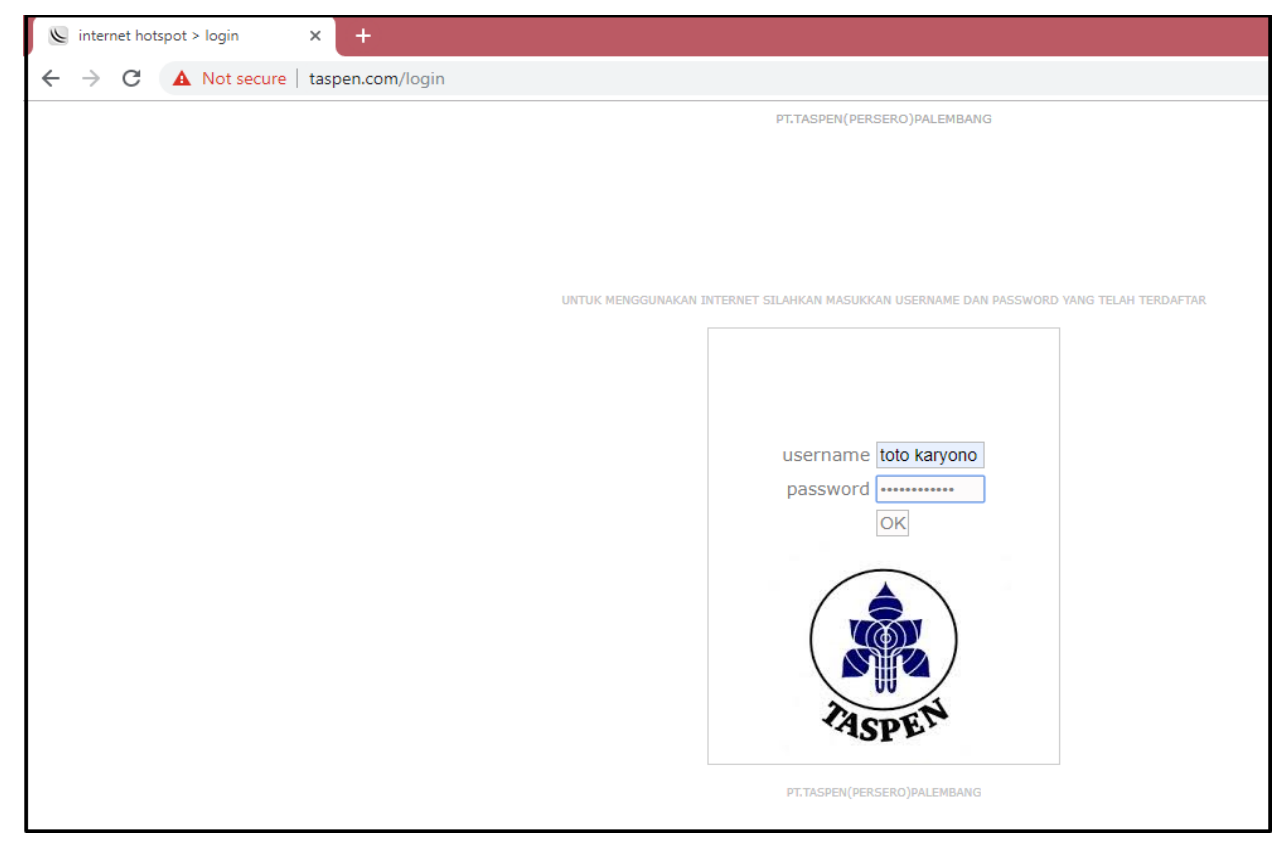

Gambar 11 Login user toto karyono

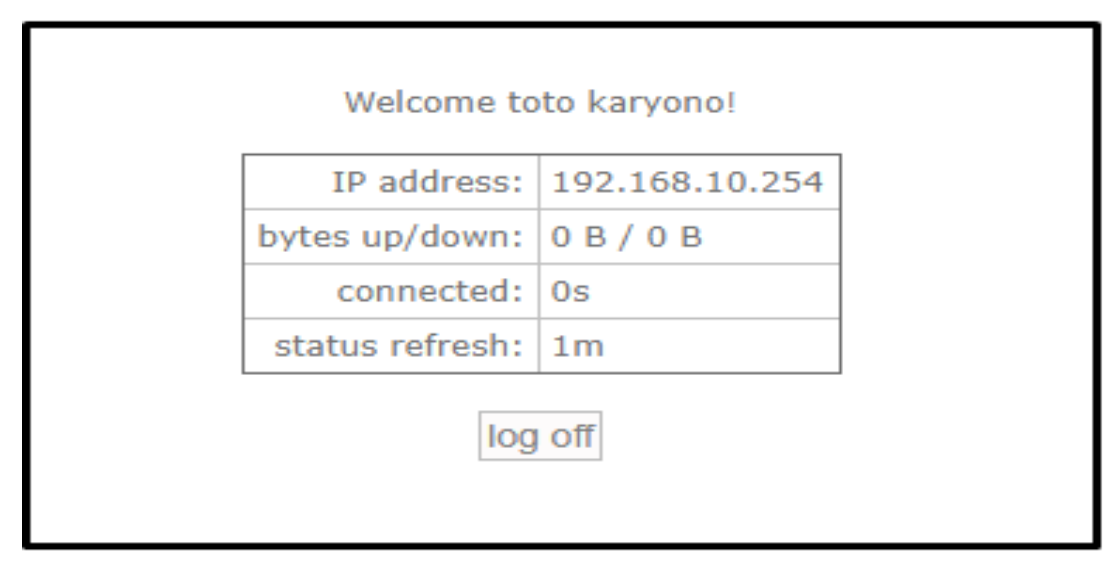

Gambar 12 User toto karyono berhasil login

Dari 4 gambar di atas dapat dijelaskan bahwa pada gambar 9 dan gambar 10 merupakan proses login pengguna bernama agung pada Jaringan Wireless PT. TASPEN (Persero) melalui RADIUS Server menggunakan smartphone serta pada gambar 11 dan gambar 12 merupakan 
proses login menggunakan Personal Computer (PC) oleh pengguna bermana toto karyono. Dapat diketahui dari Tabel 2, bahwa agung dan toto karyono merupakan 2 pengguna (user) yang telah memiliki izin (terotorisasi) serta terdaftar pada RADIUS Server untuk dapat terhubung ke Jaringan Wireless PT. TASPEN Persero dan memanfaatkan layanan internetnya.

\subsubsection{Pengujian Firewall Filter Rules}

Pengujian keberhasilan dari konfigurasi Firewall Filter Rules pada penelitian ini adalah dengan cara menguji coba akses ke media sosial Youtube, Instagram dan Facebook, apabila ketiga media sosial ini tidak bisa diakses berarti konfigurasi Firewall Filter Rules pada Jaringan Wireless PT. TASPEN telah berhasil. Akan tetapi, sebelumnya harus dipastikan bahwa user telah terhubung melalui hotspot PT. TASPEN atau user sudah dipastikan login ke Jaringan Wireless PT. TASPEN. Berikut ini secara berturut-turut adalah hasil pengujian akses media sosial Youtube pada gambar 13, Instagram pada gambar 14 dan Facebook pada gambar 15 setelah Firewall Filter Rules telah dikonfigurasikan.

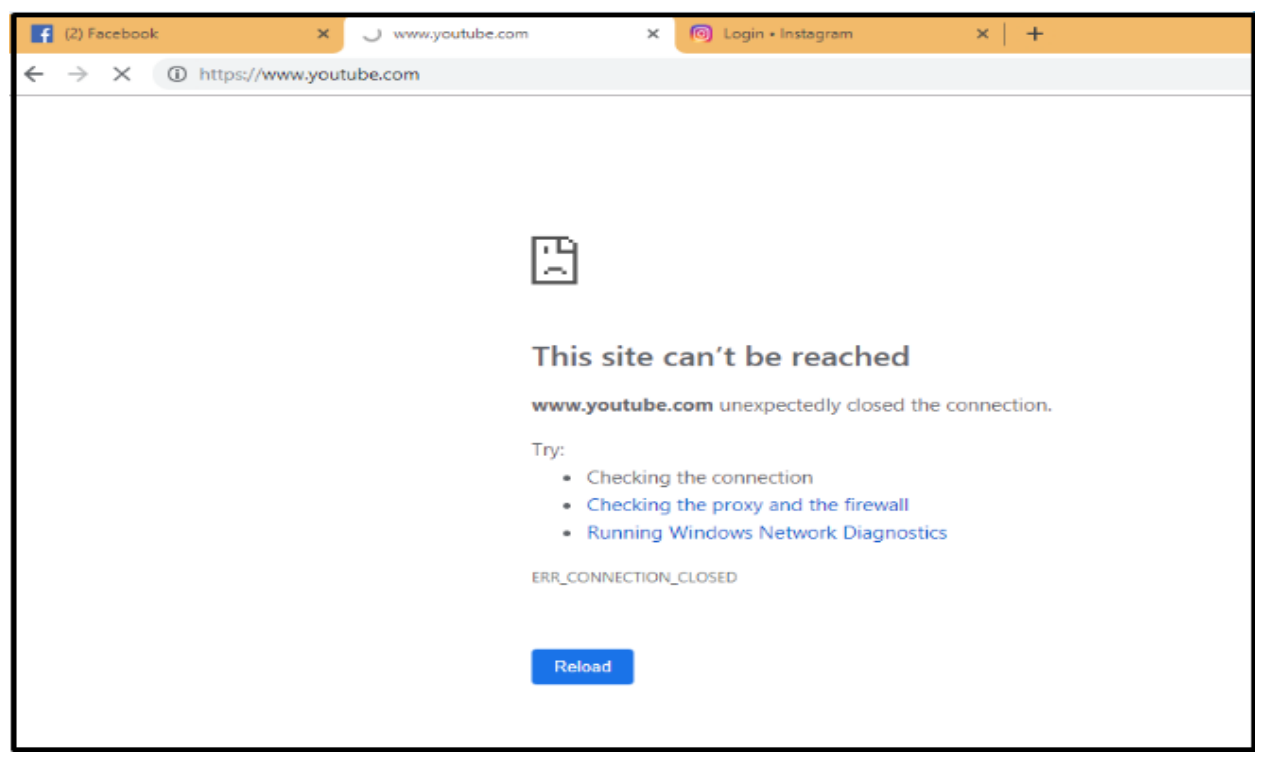

Gambar 13 Pengujian Firewall Filter Rules pada medsos Youtube

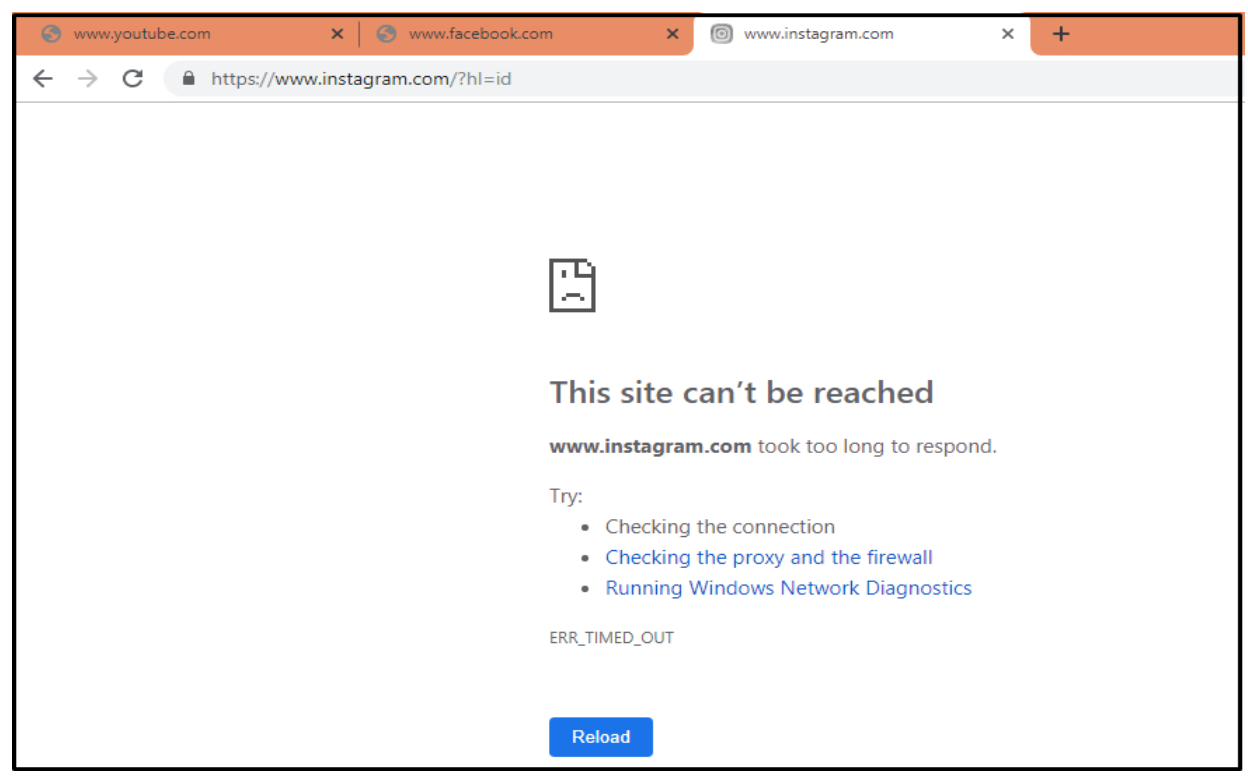

Gambar 14 Pengujian Firewall Filter Rules pada medsos Instagram 


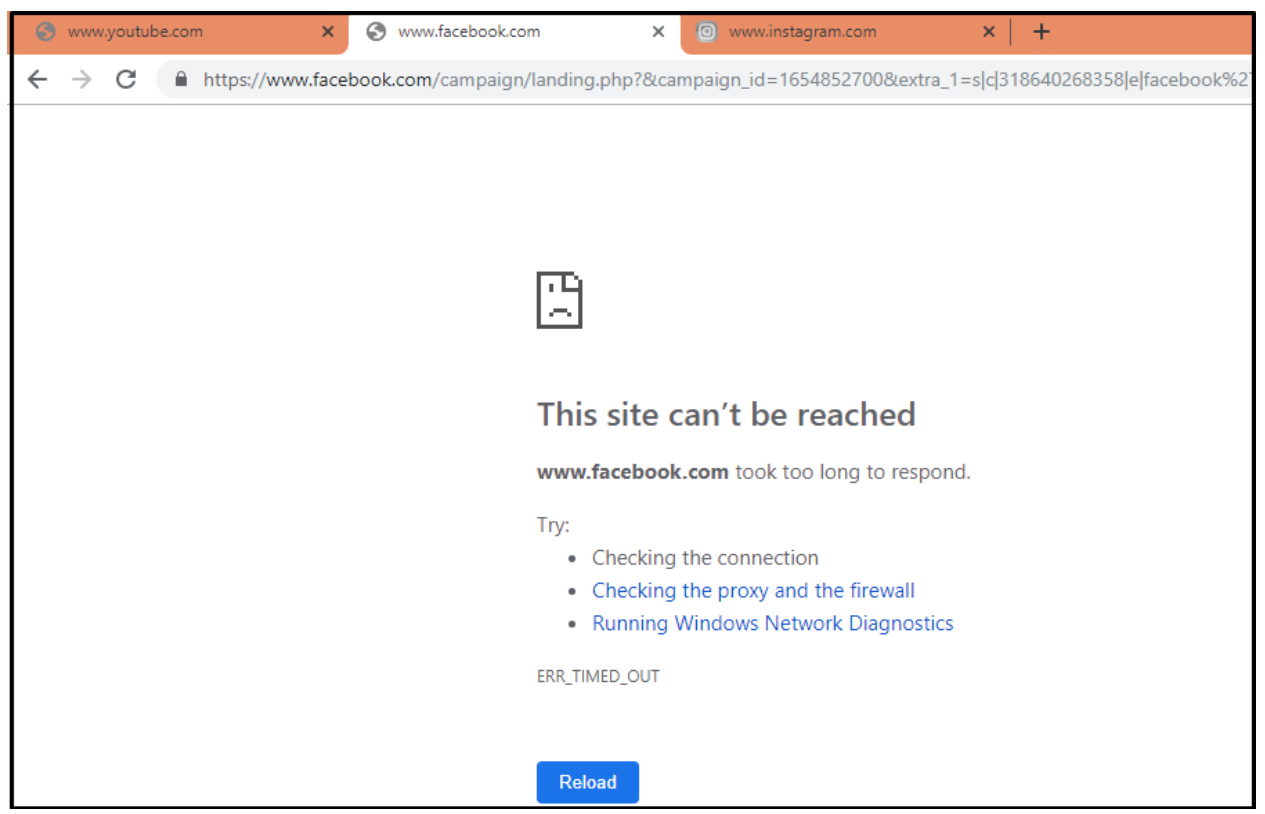

Gambar 15 Pengujian Firewall Filter Rules pada medsos Facebook

Dari analisis permasalahan yang terjadi, ketiga media sosial Youtube, Instagram dan Facebook merupakan situs yang memakan bandwidth besar saat mengaksesnya serta ketiga media sosial ini juga yang paling sering digunakan pengguna (user) saat memanfaatkan layanan internet pada Jaringan Wireless PT. TASPEN (Persero). Oleh karena itu, dengan memanfaatkan Firewall Filter Rules, maka media sosial Youtube, Instagram dan Facebook dapat diblok aksesnya saat pengguna (user) terhubung ke hotspot PT. TASPEN (Persero), dengan begitu pengguna (user) dapat lebih optimal menggunakan Jaringan Wireless PT. TASPEN (Persero) hanya untuk proses kerja (operasional) dalam kawasan PT. TASPEN (Persero).

\subsubsection{Evaluasi Hasil Penelitian}

Dari hasil penelitian yang diperoleh yaitu RADIUS Server dan juga Firewall Filter Rules, maka untuk melihat optimasi dari sebelum dan setelah penelitian ini dilakukan, peneliti menyajikan tabel perbandingan berikut ini:

Tabel 3 Evaluasi Hasil Penelitian

\begin{tabular}{|c|c|c|c|}
\hline NO & Ruangan & $\begin{array}{c}\text { Sebelum } \\
\text { Penelitian }\end{array}$ & $\begin{array}{c}\text { Setelah } \\
\text { Penelitian }\end{array}$ \\
\hline 1 & Otentikasi Pengguna (User) & Tidak Ada & Ada \\
\hline 2 & Otorisasi Pengguna (User) & Tidak Ada & Ada \\
\hline 3 & Pembatasan Pengguna (User) & $\begin{array}{c}\text { Tidak } \\
\text { Diterapkan }\end{array}$ & Diterapkan \\
\hline 4 & $\begin{array}{c}\text { Blokir Media Sosial } \\
\text { (Youtube, Instagram dan Facebook) }\end{array}$ & $\begin{array}{c}\text { Tidak } \\
\text { Diterapkan }\end{array}$ & Diterapkan \\
\hline 5 & $\begin{array}{c}\text { Optimalisasi Penggunaan } \\
\text { Bandwidth }\end{array}$ & $\begin{array}{c}\text { Tidak } \\
\text { Diterapkan }\end{array}$ & Diterapkan \\
\hline 6 & $\begin{array}{c}\text { Pembatasan Bandwidth untuk } \\
\text { masing-masing Pengguna (User) }\end{array}$ & $\begin{array}{c}\text { Tidak } \\
\text { Diterapkan }\end{array}$ & Diterapkan \\
\hline
\end{tabular}

Dari data yang ada pada tabel 3, terlihat beberapa hal yang perlu diterapkan untuk menjaga kualitas kecepatan internet (Bandwidth) pada Jaringan Wireless PT. TASPEN 
(Persero) telah diimplementasikan dengan baik. Adapun permasalahan padatnya traffic ataupun overload pengguna (user) pada Jaringan Wireless PT. TASPEN (Persero) telah diperbaiki dengan memberikan solusi pemberian otentikasi dan otorisasi pengguna (user) sebagai cara pembatasan user yang dapat terhubung pada hotspot PT. TASPEN (Persero). Kemudian, permasalahan kedua yaitu seringnya pengguna (user) saat terhubung ke Jaringan Wireless PT. TASPEN (Persero) mengakses situs dengan penggunaan bandwidth yang besar (dimana situsnya adalah media sosial Youtube, Instagram dan Facebook) juga telah diberikan solusi dengan melakukan blok akses terhadap ketiga situs tersebut dan juga membatasi bandwidth untuk setiap pengguna (user) sehingga penggunaan bandwidth lebih optimal untuk proses kerja ataupun operasional pada PT. TASPEN (Persero).

\subsection{Learning}

Dari hasil penelitian yang telah dilakukan, terlihat bahwa teknologi RADIUS Server dan Firewall Filter Rules telah berhasil dikonfigurasi dengan baik. Kemudian, dapat dipelajari bahwa dengan menggunakan RADIUS Server, maka penggunaan bandwidth menjadi lebih optimal dikarenakan hanya user-user yang telah memiliki hak akses login saja yang dapat mengakses Jaringan Wireless PT. TASPEN sehingga kualitas kecepatan internet pada PT. TASPEN menjadi lebih cepat dari sebelumnya. Tidak hanya itu, Firewall Filter Rules juga telah membatasi penggunaan terhadap tiga media sosial yang memakan bandwidth paling besar. Selain itu, baik teknologi RADIUS Server maupun Firewall Filter Rules, keduanya juga telah meningkatkan keamanan pada Jaringan Wireless PT. Taspen. Tidak hanya itu, PT. TASPEN juga dapat lebih meningkatkan keamanan Jaringan Wireless dengan menambahkan pemblokiran situs-situs lainnya yang dianggap dapat mengganggu proses data pada PT. TASPEN. Pada tahapan learning ini, juga dipelajari bahwa jangkauan dari RADIUS Server yang telah dikonfigurasikan pada Jaringan Wireless PT. Taspen adalah sejauh lebih kurang 10 meter.

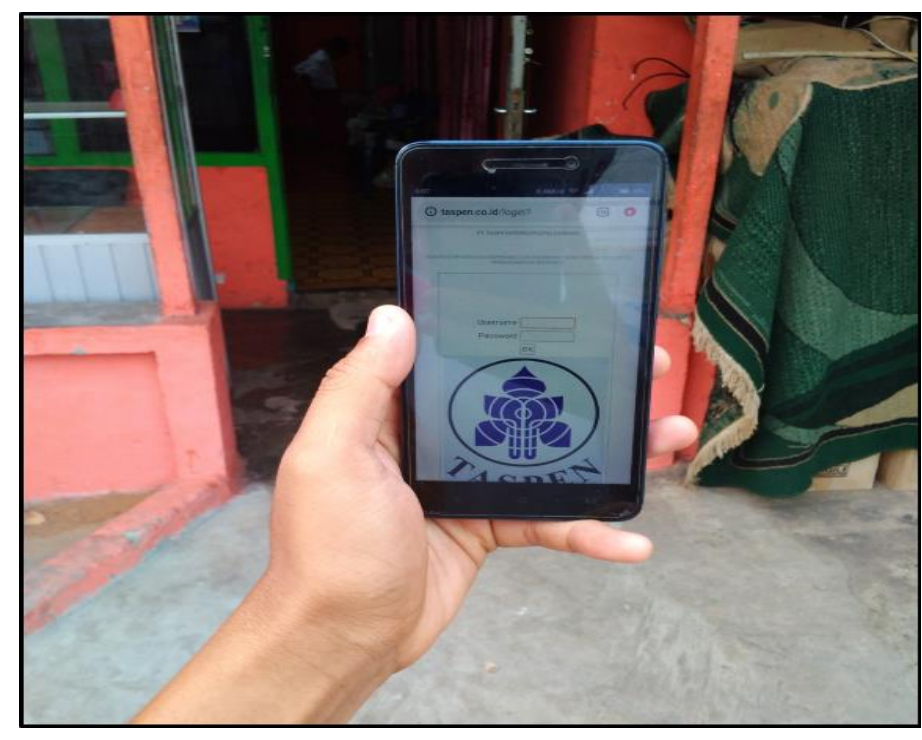

Gambar 16 Pengujian Jangkauan RADIUS Server

\section{KESIMPULAN DAN SARAN}

Dari hasil penelitian yang telah dilakukan dengan objek Jaringan Wireless PT. TASPEN yang berada di Kota Palembang adalah sebagai berikut:

1. Permasalahan kecepatan pada suatu Jaringan Wireless paling sering disebabkan oleh traffic pengguna (user) yang padat dan situs yang sering diakses pengguna (user) memakan bandwidth yang besar.

2. RADIUS Server dapat digunakan sebagai media login user ke dalam suatu Jaringan 
Wireless yang terpusat ke Mikrotik routerboard dan juga dapat memberikan username dan password yang berbeda-beda untuk setiap pengguna (user).

3. Firewall Filter Rules memiliki banyak kegunaan, tetapi pada penelitian ini dibuktikan bahwa teknologi ini dapat melakukan pemblokiran akses terhadap media sosial Youtube, Instagram dan Facebook yang menggunakan bandwidth besar untuk dapat mengaksesnya.

4. Penggunaan bandwidth yang sangat besar dapat dikurangi dengan pembatasan user dan juga pembatasan dalam akses situs-situs yang membutuhkan bandwidth besar.

5. Jangkauan dari RADIUS Server bergantung pada jenis Access Point yang digunakan, tetapi pada PT. TASPEN Kota Palembang ini jangkauan RADIUS Server lebih kurang 10 meter.

\section{UCAPAN TERIMA KASIH}

Diucapkan terima kasih kepada pihak PT. TASPEN yang berada di Kota Palembang karena telah mengizinkan untuk dilaksanakan penelitian terhadap Jaringan Wireless PT. TASPEN dan juga terima kasih kepada mahasiswa Teknik Komputer yang telah berkontribusi dalam pengumpulan data penelitian ini.

\section{DAFTAR PUSTAKA}

[1] R. N. Dasmen, "Implementasi Authentication Captive Portal pada Wireless Local Area Network PT. Rikku Mitra Sriwijaya," Regist. J. Ilm. Teknol. Sist. Inf., vol. 4, no. 2, pp. 67-80, 2018.

[2] R. N. Dasmen, "Rancang Bangun Keamanan Jaringan Wireless pada STIPER Sriwigama Palembang dengan Radius Server," J. Maklumatika, vol. 4, no. 1, pp. 19-29, 2017.

[3] H. Kuswanto, "Sistem Autentikasi Hotspot menggunakan Radius Server Mikrotik Router," Informatics Educ. Prof., vol. 2, no. 1, pp. 43-50, 2017.

[4] N. Zendrato, "Analisis Pemanfaatan Bandwidth pada Off-Time Kantor menggunakan Mikrotik dan Radius Server," Sink. J. Penelit. Tek. Inform., vol. 1, no. 1, pp. 25-29, 2016.

[5] I. G. B. P. Putra and I. P. A. E. Pratama, "Optimasi Radius Server untuk Pengaturan Alokasi Bandwidth pada Jaringan Hotspot," J. Sains dan Sist. Inf., vol. 2, no. 2, pp. 18 24, 2019.

[6] I. G. K. O. Mardiyana, "Keamanan Jaringan dengan Firewall Filter berbasis Mikrotik pada Laboratorium Komputer STIKOM Bali," in Proceedings Konferensi Nasional Sistem dan Informatika (KNS \& I), 2015, pp. 804-807.

[7] R. A. Purnama, "Optimalisasi Keamanan Jaringan Wireless menggunakan Firewall Filtering MAC Address," Indones. J. Netw. Secur., vol. 8, no. 4, pp. 43-47, 2019.

[8] Alfred and J. C. Chandra, "Pemanfaatan Firewall pada Jaringan Komputer SMK Fadilah," Indones. J. Inf. Syst., vol. 1, no. 5, pp. 422-428, 2018.

[9] R. N. Dasmen, "Implementasi Raspberry Pi 3 sebagai Wireless Access Point pada STIPER Sriwigama Palembang," J. Inform. J. Pengemb. IT, vol. 3, no. 3, pp. 387-393, 2018.

[10] W. Chandra and R. Amalia, "Sistem Informasi Pemesanan Kamar Mess PT. KAI Persero Divre III Sumatera Selatan," CESS (Journal Comput. Eng. Syst. Scence), vol. 4, no. 1, pp. 88-93, 2019.

[11] R. N. Dasmen and Rasmila, "Implementasi Raspberry Pi 3 pada Sistem Pengontrol Lampu berbasis Raspbian Jessie," JEPIN (Jurnal Edukasi dan Penelit. Inform., vol. 5, no. 1, pp. 46-53, 2019. 